\title{
О КУЛТУРОЛОШКИ УСЛОВЉЕНИМ РАЗЛИКАМА У ПОЈМОВНИМ МЕТАФОРАМА У РАЗЛИЧИТИМ ЈЕЗИЦИМА
}

У овом раду даћу веома кратак приказ културолошке лингвистике и теоријских приступа који се примењују у проучавању појмовне и културолошке метафоре. Осврнућу се на конкретна истраживања која покушавају да утврде међукултурне разлике у појмовним метафорама, али и могуће универзалне метафоре. Главни део рада је посвећен концептуализацијама времена, сликовних схема, осећања, тела, а такође и међукултурним разликама метафора које зависе и од различитих аспеката комуникације (дискурса, односно контекста у ком се налазе). Закључци истраживања могу се сажети у тврдњу да на појмовне метафоре једнако утичу и телесна искуства и културно окружење, те да је за њихово прецизније тумачење потребно узети у обзир спрегу мишљења, језика и културе.

Кључне речи: појмовна метафора, култура, културолошка лингвистика, когнитивна лингвистика, културолошка метафора, embodiment.

\section{1. Увод}

\section{1. Когнитивна и културолошка лингвистика}

Откада су у својој теорији појмовне метафоре (Conceptual Metaphor Theory, CMT) Лејкоф и Џонсон метафору истакли као когнитивни механизам а не пуку реторичку фигуру, бележе се све бројнија и разноврснија когнитивнолингвистичка истраживања метафоре. Још су ови аутори наговестили да у стварању појмовних метафора улогу игра и културна позадина, али нису детаљно анализирали однос културе, мишљења и језика. Једна од

\footnotetext{
* Универзитет у Београду, Филолошки факултет, Студентски трг 3, 11000 Београд; andjela.pen@gmail.com
} 
„слабих тачака” њихове теорије, по мишљењу многих аутора, јесте немогућност да се опишу креативне, неконвенционалне метафоре. У намери да се овај њен недостатак, као и неки други, превазиђу, појавили су се различити приступи метафори, било као њој супротстављене теорије, било као њене модификације и надоградње. Једна од њих јесте теорија појмовне интеграције Фоконијеа и Тарнера, која је омогућила још свеобухватније проучавање метафоре као когнитивног механизма у разним областима које се у великој мери преплићу са културом и идеологијом (њихов теоријски оквир се показао погодним за анализу метафоре у дискурсу, у реклами, политици, уметности). Упркос томе, пажња није много посвећивана утицају културе, у фокусу је најпре остајао когнитивни аспект (како тумачимо метафоре, каква је природа пресликавања између домена, каква је веза између телесних искустава и концептуализације и сл).

Питање о односу појмовне метафоре и културе искрсава у нарочитом светлу у потрази за универзалним појмовним метафорама. Узимајући у обзир да су људима у основи заједнички телесна и умна структура и функционисање, претпостављало се, на основу једне од главних теза когнитивне лингвистике о заснованости метафоре у телесном искуству (тзв. embodiment), да би се потенцијалне универзалије могле наћи у примарним метафорама. Међутим, истраживањима овог типа су се више откривале разлике међу језицима, што је у први план поставило проблем - чиме су оне условљене. Обично би се установило да су разлике културолошке природе, али шта то значи, и како то култура утиче на метафору, остајало је нејасно, у великој мери и због дефиниције културе која није увек прецизно утврђивана. Нова истраживања метафоре узимају ово у обзир, истовремено не губећи из вида и утицај телесних искустава, као и значај одређивања граница до којих он сеже.

Због комплексности проучаваног феномена, одговор на ово питање захтева приступ који би у себи објединио неколико различитих научних области. Културолошка лингвистика представља један такав амалгам, коме је у центру пажње управо однос језика, културе и когниције. Шарифијан (2017: 34-35) је дефинише као грану лингвистике која се заснива на когнитивној лингвистици и лингвистичкој антропологији, тачније, три научне парадигме у оквиру ње. Прва се бави језиком као феноменом који одражава умни и културни живот људи, и она наставља линију лингвистичких проучавања започету у радовима Франца Боаса. Друга је етносемантика, и проучава начине на који је знање организовано и категоризовано у различитим културама. Трећа је етнографија комуникације, која испитује комуникацију у 
ширем друштвеном и културном контексту, анализирајући друштвене норме одређене заједнице, њена уверења, вредности и сл.

Шарифијан (2017: 34) наводи да се, иако се назив културолошка лингвистика јавља и код Роналда Лангакера (1994), тек од Палмера и његовог рада Toward a Theory of Cultural Linguistics (1996) ова дисциплина утемељује као област која покушава да опише утицај културе на језик и мишљење. Културолошка лингвистика са когнитивном лингвистиком дели идеју да је значење концептуализација, али усредсређује се на културне факторе који одређују појмовну организацију (Шарифијан 2014: 118). Шарифијан $(2014 ; 2017)$ уводи појам „културолошке концептуализације”, под којим подразумева аналитичка средства у оквиру културолошке лингвистике. У њих спадају културолошке схеме, категорије и метафоре. Културолошка метафора би се могла у том смислу описати као појмовна метафора заснована на култури.

Теоријски оквири који се баве појмовном метафором, дакле, могу се груписати у две главне струје - они који акценат стављају више на утеловљеност метафоре, и они којима је у фокусу култура. Такође, приступи се разликују и по томе како тумаче однос језика, мишљења и културе. Према некима, језик је тај који утиче на нашу концептуализацију, према другима у концептуализацији главну улогу има култура.

У наредним поглављима биће више речи о поменутим приступима, кроз поређење појмовних метафора у различитим језицима. Желим да истакнем да овај рад не претендује да обухвати све приступе у културолошкој лингвистици, већ се ограничава на приказ појединих истраживања која проучавају појмовне метафоре узимајући за полазиште основне идеје у оквиру теорија које су засновали Лејкоф, Џонсон, Фоконије, Тарнер, као и њихови следбеници. ${ }^{1}$

\section{2. Појмовна метафора и култура}

Постоји неколико класификација појмовне метафоре, али оне се углавном своде на разлику између:

1 У раду је дат приказ културолошке лингвистике, онако како се та дисциплина формирала у западној традицији, док су истраживања словенских научника у оквиру лингвокултурологије изостављена. Разлог за овакво ограничење лежи у обиму рада. Наиме, концептуализације у лингвокултурологији овог усмерења се унеколико анализирају из помало другачијег угла, не усредсређујући се толико на саме појмовне метафоре, колико на лингвокултурни концепт. За разумевање овог специфичног тумачења концепта неопходно би било представити појмове као што су језичка слика света, менталитет, културни смисао и остале кључне термине лингвокултурологије у словенској литератури. 
1. устаљених и неконвенционалних метафора

2. примарних и сложених.

Примарне су оне које су директно повезане са општељудским телесним искуствима, а комплексне су сачињене од више примарних. На пример, сложена метафора ЉУБАВ ЈЕ ПУТОВАЬЕ сачињена је од примарних као што су СВРХЕ СУ ДЕСТИНАЦИЈЕ иЛИ ВЕЗА ЈЕ САДРЖАТЕЉ (Лејкоф 2008: 2627). Цинкен, Хелстен и Нерлих (2003) предлажу и поделу на телесно-засноване (корелационе) и културно-засноване (интертекстуалне). Разлика између ова два типа може се показати поређењем метафоричких исказа „Проучавање рака помакло се за корак” и „Не бисмо желели да наука прави нова франкенштајнска чудовишта” (Цинкен, Хелстен и Нерлих 2003: 8). Први се заснива на корелационој метафори НАУЧНИ НАПРЕДАК ЈЕ ПУТОВАњЕ, а другИ на интертекстуалној метафори НАУЧНИ НАПРЕДАК ЈЕ ФРАНКЕНШТАЈНСКИ ПОДУХВАТ. Потоња садржи појам Франкенштајна, културни појам који не може лежати у основи телесних искустава на начин на који је то случај у корелационим метафорама. Цинкен, Хелстен и Нерлих (2003) истичу да се однос који постоји између конвенционалних и неконвенционалних метафора преклапа са оним у ком стоје корелационе и интертекстуалне. Најчешће се устаљенима приписује универзалност, док се неконвенционалне посматрају као идиосинкратичне и под већим утицајем културе. Међутим они, међу осталим ауторима, сматрају да су чак и примарне метафоре културолошки условљене, будући да се метафоре не заснивају на лично стеченим телесним искуствима, него на одговарајућим културним моделима.

Кевечеш (2010а) узима у озбир утицај и тела и културе на појмовне метафоре, и метафоре не дели оштро на примарне или сложене, већ сматра да оне образују један континуум између те две тачке. Другим речима, разликују се према степену у ком ова два аспекта имају удела приликом њиховог формирања.

Два језика могу имати идентичну појмовну метафору која је чак и на језичком нивоу изражена у великој мери сличним средствима. Међутим, суптилне разлике у изразима откривају различите културно-идеолошке позадине, како запажа Кевечеш (2003: 315). Аутор до овог закључка долази анализирајући појмовну метафору ЉУБАВ ЈЕ ПУТОВАЬЕ и њене реализације у енглеском и мађарском језику. Истраживање је спроведено поређењем примера које су понудили Лејкоф и Џонсон (1980) у америчком енглеском, и њиховог превода на мађарски, састављеног од стране 20 мађарских студената на Универзитету у Будимпешти. Наиме, док се у енглеским 
примерима уочава да су љубавници (сапутници) активнији, одлучнији, у мађарском је чешћи случај да су они само жртве спољашњих фактора. То се види у метафори Look how far we've come, чији мађарски еквивалент има глагол jut са приближним значењем „стићи на неко место уз потешкоће”. Такође, мађарски еквивалент метафоре која у енглеском гласи We have to go our separate ways нема сапутнике у функцији субјекта, већ су путеви ти који се разилазе (Кевечеш 2003: 317). Аутор изводи закључак да то говори о генералном ставу који говорници имају према љубави и према животу. Као што сведоче метафоре, Мађари имају пасивнији приступ, чешће су „жртве” спољашњих фактора, и то је повезано са њиховим фатализмом. Американци су, с друге стране, одлучнији у доношењу одлука. О разликама не сведочи само форма и одабир речи у датим изразима, већ и њихова употреба. Мађари неће у свакодневном говору употребљавати метафоричне изразе да говоре о сопственој љубавној вези, већ више у ситуацијама када доносе суд о другим људима, док Американци говоре о себи експлицитније. Како тврди Кевечеш (2003: 319), ове чињенице одражавају степен екстровертности и интровертности америчке и мађарске културе.

У оваквим истраживањима постоји могућност да се приликом тумачења поткраде и понеки субјективни суд - чак и када је анализа објективна, закључци који се на основу добијених резултата изведу не морају бити објективни. Највећа опасност јесте у доношењу уопштених судова о карактерима читавих народа или култура. Без обзира на то што би се са тврдњом да су Американци екстровертнији од Мађара можда већина сложила, свакако треба бити обазрив када се такве тврдње износе на основу малог језичког корпуса. До сличних увида о екстровертности долази и Ју (1995: 74-75) поредећи две метафоре са циљним доменом среће у кинеском и америчком енглеском. У кинеском се јавља појмовна метафора CРЕЋА JЕ ЦВЕЋЕ У СРЦУ, која није забележена у енглеском, док је код Американаца једна од честих метафора која се не појављује у кинеском БИТИ СРЕЋАН JE HЕ БИТИ НА ЗЕМљИ.

Други проблем у Кевечешовој студији о метафори ЉУБАВ ЈЕ ПУТОВАњЕ јесте и почетна грађа - постоји вероватноћа да би мађарски превод метафоричних израза био другачији да га је нека друга група људи сачињавала. Осим тога, поједини аутори износе приговоре на избор испитаника у лингвистичким истраживањима уопште, будући да су то обично студенти из западних, богатијих земаља, који стога не могу представљати репрезентативан узорак који ће описати народ у целини (Бернардес 2013: 6). 
Међутим, главни закључак који Кевечеш изводи тиче се природе метафора уопште, и у складу је са бројним истраживањима (о којима ће бити више речи). Кевечеш (2003: 319) каже да су у метафори когнитивна и културна компонента спојене у јединствен појмовни комплекс. Комплексна метафора ЉУБАВ ЈЕ ПУТОВАЮЕ изграђена је од примарних метафора заснованих на универзалним телесним искуствима (као што је нпр. СВРХЕ СУ ДЕСТИНАЦИЈЕ), али је она мотивисана и културолошки (у овом случају, то су вредности, поглед на љубав и њен положај у мађарској и америчкој култури), не само когнитивно, те се стога разликује од једне културе до друге.

Појмовне метафоре могу имати различите облике и у оквиру једне исте културе. Кевечеш (2006) наводи неколико димензија по којима варирају, то су: друштвена, регионална, стилистичка, субкултурална и индивидуална. Занимљив пример за друштвену димензију јесу метафоре које мушкарци користе када говоре о женама (најчешће: ЖЕНЕ СУ (МАЛЕ) КРЗНЕНЕ ЖИВОТИЮЕ, ЖЕНЕ СУ СЛАТКА ХРАНА), спрам метафора којима жене описују мушкарце (МУШКАРЦИ СУ ВЕЛИКЕ КРЗНЕНЕ ЖИВОТИЬЕ; жене ретко говоре о мушкарцима као о слаткој храни, али понекад користе домен хране уопште када је реч о сексуалној сфери) (Кевечеш 2006: 59). Регионална димензија подразумева феномен преобликовања метафоричких образаца у одређеном језику који се дешава када се његови говорници преселе у неку другу област. То се догодило са африкансом када је из Европе доспео у Јужну Африку, и тада је добио мноштво нових метафора заснованих на доменима природе и животиња (Кевечеш 2006: 59). Субкултурне разлике аутор описује кроз метафору ДЕПРЕСИЈА ЈЕ ТАМНИЧАР, која је присутна међу депресивним људима (условно се могу сматрати посебном групом), док недепресивни људи користе метафоре ДЕПРЕСИЈА ЈЕ ТЕШКА; ДЕПРЕСИЈА ЈЕ МРАК... (Кевечеш 2006: 67). Важно је што у својој анализи наведених метафора Кевечеш увиђа значај и конкретно личног искуства у њиховом стварању - објашњење за ову разлику он види у томе што се депресивни људи (за разлику од недепресивних) осећају „заробљено”, имају жељу да се „ослободе” и томе слично, те управо ова метафора најбоље осликава њихово ментално стање. ${ }^{2}$

2 Кевечеш (2010b: 226) даје примере и како „лична историја” утиче на стварање метафоре - политичари су у кампањи користили спортске метафоре, али је спорт који је изабран за изворни домен зависио од тога којим спортом се сам политичар бавио у животу. 


\section{2. Културолошке метафоре у литератури}

\section{1. Концептуализација времена}

Време, као феномен који није доступан чулном искуству, према становишту когнитивне лингвистике, поима се преко других, чулно ближих домена, међу којима посебно место заузимају домен простора и кретања кроз простор. Како примећују Синха и др. (2011: 139), једна од главних претпоставки когнитивне лингвистике - да су когнитивни процеси универзални - довела је до тога да се у когнитивнолингвистичкој литератури појмовна метафора BPЕМЕ JЕ ПРОСТОР такође сматра универзалном (уп. Еванс 2007, Фоконије и Тарнер 2008). Од ове тврдње се полази као од аксиома, и испитивања су усмерена углавном на утврђивање разлика у томе да ли се просторна раван протеже хоризонтално, вертикално и у ком смеру „тече” време - уп. Бородицки (2001), где ауторка кроз низ психолингвистичких експеримената тежи да докаже да језик утиче на мишљење поредећи различите концептуализације времена у мандаринском кинеском и енглеском (у оба језика се користе „хоризонталне” метафоре, с тим што се у мандаринском осим тога користе и „вертикалне”).

Пресликавање време-простор јесте потврђено у великом броју типолошки и генетски удаљених језика, међутим, како показују у свом раду Синха и др. (2011), постоје језици код којих то није случај, као што је амондава језик, којим се говори у Амазонији. Аутори су на основу неколико експеримената са говорницима овог језика дошли до закључка да се у њиховој култури време сагледава више квалитативно него квантитативно, те да у њој не постоји метафора ВРЕМЕ JE ПРОСТОР. Аутори овакав закључак изводе како на основу језичких, тако и на основу културолошких чињеница. Њихова анализа је свеобухватна и опсежна, јер описује целокупан начин живота и друштва у мери у којој је повезан са концептом времена. Тако су у разматрање ушле и одређене друштвене праксе: на пример, узраст се не рачуна према годинама старости, већ према кључним тренуцима када човек добија нову друштвену улогу, а са њом и ново име (Синха и др. 2011: 147). Осим тога, у овој култури не постоји календар, а дани се не деле по сатима, него према активностима које се врше у конкретно доба дана (у складу с тиме, делови дана носе називе попут „онда када смо гладни”, „онда када почињемо посао”...) (Синха и др. 2011: 153). Што се тиче самог амондава језика, једна од његових важнијих одлика, која доприноси оваквој концептуализацији времена, јесте 
и одсуство морфолошког маркирања времена на глаголима, као и систем бројева који се састоји од само 4 речи (Синха и др. 2011: 148).

Тврдња да је метафора ВРЕМЕ JЕ ПРОСТОР универзална била је мета у великој мери основаних оптужби о англоцентричности у научној парадигми. Бернардес (2013), на тренутке и помало острашћено, истиче да преовлађујућа употреба енглеског језика у лингвистици, чак и када се анализира неки други језик, доводи до озбиљних заблуда о универзалности језичких појава. Он није једини аутор који се залаже за нова решења у том погледу. Вјежбицка, која се не бави у ужем смислу појмовном метафором, али проучава културолошке концепте, семантичке и културолошке универзалије и варијације на лексичком нивоу у различитим језицима, у својим радовима развија посебан метајезик за семантичко описивање и поређење, метајезик који тежи да буде неутралан, састављен од „природних речи” (свакодневних, дакле, не термина), несводивих на мања значењска језгра, којим би се могло парафразирати било које друго значење. Ни њен приступ није без проблема, што се може видети по било којој парафрази осећања коју предлаже (пре свега јер су контраинтуитивне - на основу дате парафразе тешко је погодити о ком осећању се ради). Како култура и начин размишљања самог истраживача могу већ у почетној тачки бити проблем за испитивање језичких универзалија сликовито описује Вјежбицка (1986) говорећи о листи универзалних људских осећања коју су саставили Изард и Бушлер (1980: 168). Њу чине: заинтересованост (interest), радост (joy), изненађење (surprise), туга (sadness), бес (anger), гађење (disgust), презир (contempt), страх (fear), стид/ срамота (shame/shyness) и кривица (guilt). Вјежбицка (1986: 584) тврди:

Уколико листе сличне наведеној треба да поброје универзална људска осећања, како то да су сва она тако фино идентификована помоћу речи енглеског језика? На пример, у пољском не постоји реч која би у потпуности била еквивалент енглеској речи за гађење. Шта би се десило уколико би психолози који разрађују тезу „основних људских осећања” били матерњи говорници пољског, а не енглеског? Да ли би у том случају укључили „гађење” у своју листу? Тако језик аустралијских Абориџина, гиђингали, не разликује лексички „страх” од „срамоте”, већ у једној лексичкој јединици обухвата осећања сродна онима које енглески језик одређује као „страх” и „срамоту” (Хијет 1978: 185). Да су истраживачи били матерњи говорници гиђингалија а не енглеског, да ли би и тада тврдили да су страх и срамота основне људске емоције, специфичне и одвојене једна од друге? (Вјежбицка 1986: 584) 
Исто важи и за проучавање појмовне метафоре, наиме, како тврде Цинкен, Хелстен и Нерлих (2003: 7), приступи појмовној метафори зависе од тога шта одређени аутор сматра за најбољи пример метафоре.

Још један методолошки проблем који се тиче примене ,западњачке логике" на друге језике и културе јесте и онај који објашњава Палмер (2006: 266) када говори о категоризацији родбинских односа у различитим језицима племена - он поставља питање да ли су дате категорије заиста присутне као такве у самим тим језицима или су оне само пуки аналитички конструкти научника. Тако се и приликом проучавања појмовне метафоре мора водити рачуна о томе да се на уочене језичке чињенице не транспонује поглед на свет самог истраживача. Бернардес (2013) исправно уочава да је немогуће схватити неку концептуализацију у другом језику осим кроз призму самог тог језика, без превода на, најчешће, енглески (јер се тада анализира енглески, а не језик који испитујемо). У супротном, могу се превидети важне чињенице, као што је то случај са концепцијама времена у културама које време не доживљавају као посебну димензију, већ га сматрају нераздвојним од простора.

Догађа се да се у једном језику кроз време одређена појмовна метафора мења. У том смислу посебну пажњу завређује феномен међукултурних утицаја, будући да културне промене доводе до промена у језику, а тиме донекле и у појмовом систему (Бернардес 2013: 27). Тако се у калули језику, који се говори у Папуи Новој Гвинеји, под утицајем хришћанских мисионара развио систем за означавање времена какав раније није постојао (Шифелин 2002), што је донекле променило и калули језик и саму концептуализацију времена код његових говорника. Један од примера за такве иновације јесте увођење нових речи за означавање временских сегмената који одговарају западноевропској подели времена. Заједница говорника калули језика није имала појам седмице, нити дана у седмици, и за њих су сковане речи додавањем наставка за инструментал бројевима 1-7, те је тако, на пример, реч за понедељак одговарала инструменталу броја 1 да би касније ове речи употребом биле поименичене (Шифелин 2002: S9-S10). Мисионари су инсистирали на оштром раздвајању „грешне” прошлости од садашњости која је обележена крштењем и новим животом према хришћанским веровањима, а управо је та усредсређеност на ново „сада” утицала и на језичке изборе у калули језику и примену језичких иновација (Шифелин 2002: S16). Говорници калулија су пре примања хришћанства важне догађаје своје заједнице претежно везивали за простор у ком су се догодили, не толико за кален- 
дарско време, а утицај мисионарске реторике је допринео томе да се концептуализација идентитета, заједничке прошлости и митологије, унеколико промени у смеру занемаривања простора и потенцирања само временског аспекта (Шифелин 2002: S16).

\section{2. Примарне метафоре и сликовне схеме}

Сликовне схеме су когнитивни обрасци који настају кроз телесна искуства (перцепцију, телесне активности, манипулацију објектима). Оне су основе за разна метафоричка пресликавања као изворни домени. Њима је најчешће приписивана универзалност, међутим, Кимел (2004) сматра да се оне не могу узимати као универзалне когнитивне структуре, пре свега јер се актуализују у конкретном окружењу и зато што могу бити емотивно обојене. Оне, дакле, никада нису присутне као одвојени ентитети, већ формирају сложену мрежу схема.

Палмер (2006: 264-265), у истом духу, истиче да су чак и оне лингвистичке категорије које су засноване на најбазичнијим телесним искуствима заправо обликоване културним окружењем. Културу одређују и географске одлике места у ком нека заједница живи - на северу су, услед климатских услова другачије куће, одећа, активности људи, технологија која се користи за грејање/хлађење, те је тако доживљај температуре неког риболовца са севера другачији од доживљаја какав би имао земљорадник који живи ближе екватору. Према томе, чак ни примарне метафоре не могу претендовати на универзалност, будући да су готово сви домени људског искуства у некој мери дефинисани културом. Другим речима, две заједнице могу делити појмовну метафору, али сликовна схема на којој је изграђена варираће у зависности од културе. Како то илуструје Палмер (2006: 265) на примеру метафоре ЉУБАВ ЈЕ ПУТОВАҢЕ, сликовне схеме пута у контексту урбаног шопинг-центра и узоране њиве нису исте.

Ове тврдње су у складу са резултатима истраживања које су спровели Синха и Де Лопес (2000) испитујући сликовну схему садржавања код деце која усвајају дански и запотек језик. Аутори су утврдили да култура игра велику улогу на обликовање сликовне схеме садржатеља. Они, наиме, претпостављају да употреба свакодневних предмета није „културно неутрална” и да утеловљује различите концептуализације. Ствар је у томе да су деца која усвајају дански дала другачије одговоре у експериментима са садржатељима од деце која усвајају запотек језик. Аутори ове разлике објашњавају 
чињеницом да се у данској и запотек култури садржатељи другачије користе - у потоњој се користи мање предмета, али су они вишефункционални, што значи да се могу користити и „наопачке”. Другим речима, у данској култури чаша искључиво служи као садржатељ, те нема никакву функцију када је окренута наопако; док код говорника запотек језика, разне врсте садржатеља могу да се користе и да нешто прекрију одозгоре. Према становишту аутора, ова употреба условљена културом утиче на прелингвистику концептуализацију, а она се осликава у језичкој структури (у запотек језику се користи један исти предлог за релације $y$ и испод). На бази ових открића, аутори предлажу проширење појма утеловљење тако да се њиме обухвате и културне концептуализације. Како се може видети, ни примарне метафоре формиране директно помоћу сликовних схема не могу претендовати на универзалност, јер је и само тело друштвени конструкт. Сликовне схеме, према томе, не формирамо на основу сопственог личног телесног искуства већ кроз утицај друштвених модела.

\section{3. Концептуализација осећања}

Кевечеш (2010а) културу и језик сагледава кроз „стварање значења”, то јесте, и језик и култура су „мреже смисла” које људи стварају и разумевају. Стварање значења се одвија у оквиру више различитих контекста, и кључни елементи који учествују у том процесу јесу физичко и друштвено окружење. Иако људи деле исте когнитивне функције, когнитивне операције се не користе у свим заједницама једнако, што доводи до различитих појмовних система у културама. Појмовна метафора представља когнитивну операцију која на највидљивији начин подстиче различитост концептуализација, а међу њима, то се можда најбоље уочава у метафорама за осећања. Кевечеш (2008) заступа тезу да су метафоре за осећања у највећој мери универзалне на општем нивоу, будући да су телесна и физиолошка испољавања осећања универзална, али да се разлике тичу културних специфичности. Другим речима, репертоар телесних искустава даје подлогу за универзална поређења, али који елемент ће бити употребљен или доминантан у метафори и на који начин - то зависи од културе. Кевечеш (2006: 68) ове разлике објашњава појмом „искуствени фокус”. На пример, бес се физиолошки испољава кроз осећај топлоте у телу и повишени крвни притисак, и најчешће се конципира кроз метафору БЕС ЈЕ ТОПЛОТА, а бесна особа као САДРЖАТЕЉ ПОД ПРИТИСКОМ. У кинеском је акценат на притиску, а у енглеском и на при- 
тиску и на топлоти. При томе, у енглеском се јавља ужа метафора БЕС JЕ ТОПЛА ТЕЧНОСТ У САДРЖАТЕЉУ, док се у кинеском бес конципира као гас. Ју (1995: 81) ово објашњава специфичним културним појмом qi у кинеском, који је обликован кроз дугу традицију кинеске медицине и филозофије (са кључним појмовима хомеостазе, хармоније, супротности). Qi је једна од основних супстанци које сачињавају људско тело и сматра се физиолошким покретачем унутрашњих органа. Разлог за одабир гаса уместо течности лежи и у томе како се у јапанској култури појаве класификују и повезују, а у томе велику улогу има идеја јина и јанга (Ју 1995: 82).

Што се тиче дела тела у коме се бес појављује, у енглеском је у питању цело тело, док се у мађарском посебно издваја глава (Кевечеш 2010b: 216). У јапанском је то hara, концепт који има посебно место у кинеској култури (буквално би се могао превести као стомак, али заправо се односи на одређено енергетско поље тела). Кевечеш (2010а) говори о овом појму следеће:

Како тврди Мацуки (1995), изгледа да у Јапану постоји читав скуп концепата изграђен око појма hara. Његов садржај чине истина, праве намере и прави селф (назван honne). Појам honne је супротстављен „друштвеном лицу”, то јесте tatemae. Тако, када Јапанац контролише свој бес, он скрива свој приватни, истински, најдубљи селф, и показује друштвено лице које у датој ситуацији одговара прихваћеном понашању. Концепт hara је умногоме утицао на јапанско поимање беса кроз векове. (Кевечеш 2010а: 65)

Герартс и Гронделарс (1995, цитирано према Кевечеш 2006: 64) дају објашњење за то што се у западној култури бес поима као течност - реч је о погледу на људски организам који се усталио још у средњем веку у концепту 4 телесне течности (крв, лимфа, црна и жута жуч), које одређују четири типа карактера. ${ }^{3}$

Осим различитог „искуственог фокуса”, култура утиче и на различито „фрејмовање” метафоре (Кевечеш 2008: 392-393). То значи да се у два језика могу пронаћи метафоре са истим елементима, али да се они сагледавају из другачијих перспектива. Пример је метафора ПОЖУДА ЈЕ ТОПЛОТА у енглеском и чага језику (примери су преузети из Еманишн 1995) - израз „Она гори” у енглеском значи да она осећа пожуду, док у чага значи да је сек-

3 Концептуализација беса која се главним делом заснива на телесним манифестацијама ове емоције, у српском језику одговара западноевропском моделу који подразумева топлоту и течност под притиском. Уп. Драгићевић (2010), где је могуће обавестити се и о појмовним метафорама са доменом беса/љутње специфичним за српски језик, а у којима превагу над телесним има културолошки аспект. 
суално привлачна. Метафора, дакле, има исте изворне и циљне домене, али се разликује њихова употреба. Кевечеш (2008) описује и појаву да се у једној истој култури кроз време метафора мења. Љубав се сада у америчкој култури поима кроз метафору економске размене, док је раније преовладавала метафора ЉУБАВ ЈЕ ЈЕДИНСТВО. У викторијанско доба се пријатељство описивало метафором која се у савремено доба користи за романтичну љубав и страст, кроз домен ВАТРЕ (пријатељство је било горење за неким), а пријатељство је почело да се конципира као приврженост слабијег интензитета, кроз домен ТОПЛИНЕ (Кевечеш 2010b: 222-223).

Дакле, када је реч о поимању осећања, Кевечеш кроз низ својих студија о метафорама, осећањима и култури износи чврсте аргументе за тврдњу да физиолошка универзалност осећања представља само потенцијалну базу за пресликавања, док културно окружење одређује специфичан облик који ће метафора попримити - она „попуњава” делове универзалне шеме дате телесним искуством (Кевечеш 2008: 394).

\section{4. Концептуализација (делова) тела}

Већ је било речи о утицају телесних искустава на појмовне метафоре, из угла који је превасходно у фоксусу имао њихову универзалност. Међутим, Касанто (2009) поставља питање да ли различитости у самом телу доводе до различитих концептуализација. У свом раду испитује појмовну метафору ДЕСНО ЈЕ ДОБРО, која се због своје распрострањености у удаљеним културама може сматрати универзалном. Експеримент је показао да поимање домена доброг и лошег кроз просторну оријентацију није исто код десноруких и леворуких људи. Леворуки људи теже да добро повезују са левом страном. Објашњење за заступљеност метафоре ДЕСНО ЈЕ ДОБРО лежи у томе што су десноруки људи већина, те је овај концепт постао уврежен и у различитим културама (Касанто 2009: 365). Ипак, како није искључено да на деснорукост/леворукост може утицати и сама култура, будући да се у многим друштвима деца уче такорећи да буду деснорука упркос израженој склоности да се чешће користе левом руком, ову ауторову претпоставку треба узети донекле са резервом.

Као и Кевечеш, Ју (2008: 249) сматра да је тело извор за метафору, а култура филтер. Обојица истичу значај метонимије као везе између телесног искуства и метафоре. Ју (2008) анализира комплексне метафоре примењујући посебан поступак њиховог декомпоновања, приликом ког открива од којих 
елемената су сачињене (којих метафора, метонимија и тврдњи). Он тврди да се тиме могу открити различите структуре појмовних метафора, и да ће само у оним културама у којима се појављују све компоненте спојене на исти начин појмовна метафора бити иста. Анализом показује да кинески и енглески језик деле метафоре ПРЕСТИЖ ЈЕ ЛИЦЕ и ДОСТОЈАНСТВО ЈЕ ЛИЦЕ. Оне се, међутим, разликују по својој распрострањености, конвенционализованости, а разликују се такође и њихове елаборације. На пример, енглески идиом save face значи ,сачувати достојанство и самопоштовање”. У кинеском се осим одговарајућег еквивалента јавља и метафора са другачијом елаборацијом - постоји мноштво израза који значе „сачувати нечије достојанство”. То показује да је у кинеској култури важно сачувати и туђе достојанство поред свог, и како Ју (2008: 257) тумачи, разлог за ово јесте чињеница да је у кинеском друштвеном животу појам „лица” односно „достојанства” централни појам.

Постоји богата литература о метафорама са доменом делова тела и органа, посебно када је реч о домену срца. Гутијерес Перес (2008) пореди појмовне метафоре са срцем у 5 језика (енглески, немачки, италијански, шпански, француски). Ауторка предлаже нека тумачења и наглашава да су њене формулације појмовних метафора само могућа решења те да би се могло доћи и до другачијих тумачења. Ова врста свести приликом истраживања је врло важна, јер, као што је било речи поготово о концептуализацији времена, постоји тежња да се неке претпоставке олако узимају као чињенице, или, с друге стране, постоји опасност да се уопште не уоче могуће методолошке недоследности због концепата самог истраживача за које није ни свестан у којој мери су обликовани културом. Гутијерес Перес (2008) утврђује да се метафоре у 5 изучаваних језика разликују углавном у погледу циљног домена који се објашњава путем срца, као и у погледу елаборације. Постоје метафоре специфичне само за један језик. Али ипак, може се рећи да срце концептуализује приближно једнако, пре свега као центар осећања. Није у свим културама, међутим, срце орган у ком су смештена осећања. У турском је то јетра (Гутијерес Перес 2008: 31), као и у индонежанском, у ком представља средиште и умне активности, што Сајахан (2008) објашњава старим културним моделом у Индонезији повезаним са ритуалима и обожавањем јетре, која се сматрала местом где пребивају истина и човекова срж. Објашњење за делимичну универзалност и делимичну различитост Гутијерес Перес (2008) даје у истом духу као и други аутори поменути у овом раду - у суштинској заснованости појмовне метафоре и у култури. 
Сличне метафоре у различитим културама могу имати другачије емотивне и вредносне импликације и другачије идеолошке функције (Кимел 2004: 284). Тако (иако се у кинеском и немачком срце поима као садржатељ за осећања) у немачком брзо ударање срца означава радост, док у кинеском појачана активност срца карактерише негативна осећања (страх пре свега). Аутор каже да Немци и Кинези другачије доживљавају лупање срца, и да то има везе и са идеалом хармоније у кинеској култури, према коме се празно и мирно срце доживљава као усклађено.

\section{5. Метафора и комуникација}

Савремене тенденције у лингвистичким дисциплинама одликују се све већим интересовањем за метафору у дискурсу. Немали број аутора истиче да се појмовне метафоре не могу посматрати изоловано, ван контекста, већ се мора узети у обзир и њихова улога у конкретном дискурсу у ком су употребљене. Пошто метафора један аспект појаве ставља у први план а други занемарује, а будући да се једна иста метафора у зависности од контекста може тумачити на више начина, она је погодно средство за обликовање идеологије. Појмовне метафоре, дакле, нису само условљене дискурсом, већ га и саме могу обликовати. Метафоре се стратешки користе у политици и медијима, али метафора може бити и подстицај за критичко мишљење и субверзију (Кимел 2004: 279), због своје особине да ствара нове везе између дотад неповезаних домена, да преобликује дотад успостављене и тиме пружи нови поглед на ствари.

Како анализа суптилних разлика између наизглед идентичних појмовних метафора у два различита културна контекста може открити другачију идеолошку позадину, показује Богетић (2018) у свом раду о метафорама о језику у српском и енглеском. Она предлаже посебно методолошко средство, дискурсне метафоричке оквире, којим се могу описати различити нивои концептуализације и општости који формирају друштвено значење метафоре. Примери из корпуса показали су да су метафоре о језику у енглеском и српском најчешће говориле о насиљу над језиком. Ауторка, међутим, применом дискурсних метафоричких оквира открива да представе о угрожености српског и енглеског језика нису једнаке у ове две културе. У представи о насиљу над српским језиком непријатељи су страни језици, док су непријатељи енглеског необразовани слој друштва, савремене технологије и омладина која „квари” језик. 
Култура утиче и на тумачење метафоре у комуникацији. Литлмор (2003) је показала да саговорници теже да метафору интерпретирају у складу са својом културном позадином, то јесте, претпоставкама и очекивањима формираним на основу ње, али да погодан контекст може да спречи могуће неспоразуме.

Шарифијан (2014) говори о специфичним комуникативним неспоразумима између Абориџина и других заједница у Аустралији, заснованих на разликама у култури које су узроковале разлике и између варијанте енглеског коју говоре Абориџини и оне која се говори у Аустралији. Аутор истиче да разлике у концептуализацијама негативно утичу на Абориџине, стварајући озбиљне последице поготово када су у питању медицински, правни и образовни дискурс. Неспоразум је омогућен већ и самим тим што, због сличности језика, није присутна свест о потенцијалним разликама. Наиме, специфична друштвена организација Абориџина утицала је на то да поједине речи и појмови немају исти опсег као у аустралијском енглеском - мама код Абориџина подразумева и оно што се енглеским означава речју aunt, кућа је за Абориџине „моја кућа” једнако као и „кућа бабе и деде”. Када је реч о сложенијим појмовима из области духовности, ту су неспоразуми још дубљи, будући да, како Шарифијан (2014) истиче, оно што неабориџини могу протумачити као фигуративни израз, за Абориџине има дословно значење. Тако метафора ЈА САМ ЗЕМЉА у абориџинском енглеском није реторичка фигура, већ израз који дословно изражава дубоко уверење Абориџина о њиховој повезаности са прецима и земљом, развијено на темељу њихове космогоније и легенди према којима се преци доживљавају као део земље, а потомци као део предака.

С друге стране, постоје пресликавања које су Абориџини преузели из западне културе, али су она у њиховом културно-когнитивном систему добила другачији облик, а пример за то је домен медицине. Аутор наводи транскрипт аутентичне изјаве једне Абориџинке и објашњава је на следећи начин:

У овој изјави саговорница се присећа како јој је једном мајка била болесна и како је саопштила наредног јутра да су јој дошли „они” и дали јој неки „лек” чији је укус и даље осећала. Описала је да је након лека прво имала жељу да виче, а затим се осетила примораном да се опусти. Немајући у виду неопходну културолошку позадину, њени слушаоци би највероватније мислили да се „они” односи на медицинске стручњаке који су мајку посетили у неком тренутку и дали јој сируп или таблету. Међутим, у даљем разговору са саговорницом, испоставило се 
да је њена мајка говорила о прецима који су њену болест третирали употребљавајући своје исцелитељске моћи. И овде непознавање културне схеме која лежи у основи дискурса попут описаног, често узрокује неспоразуме између абориџинских и неабориџинских говорника језика. (Шарифијан 2014: 124)

Дакле, као што закључује и Литлмор (2003: 66), када су у међукултурној комуникацији присутне метафоре засноване на одређеним културним вредностима, погледима на свет, постоји могућност неспоразума уколико и друга култура не негује исте вредности на исти начин.

У дискурсу посебну улогу имају креативне метафоре, и оне представљају простор за велике варијације између култура, будући да домени могу бити уско специфично-културне појаве. То могу бити неке референце познате само у одређеној култури (на пример филм), али може бити и неки „обичнији” домен, као што је кућа - метафоре ће се разликовати јер се и сами типови кућа разликују од културе до културе. Уз то, као што потврђују горенаведена истраживања, чак ни најбазичнија телесна искуства не постоје изоловано од културе.

\section{3. Закључак}

Резултати бројних проучавања универзалности и варијације појмовних метафора у различитим језицима у великој мери су сагласни са тиме да у формирању појмовне метафоре улогу играју и телесна искуства али и културно окружење. Тело и култура представљају две тачке континуума дуж ког су појмовне метафоре распоређене зависно од тога који елемент у њима преовлађује. Углавном се показало да је тешко наћи универзалне појмовне метафоре и да је значајан утицај културолошких фактора разлог томе. Метафоре не варирају само у погледу различитих култура, већ се и у оквиру једне исте културе могу пронаћи варијације (и у синхронијској и у дијахронијској равни). Оне се тичу различитих димензија културе (друштвене вредности, друштвено раслојавање, историја, лична историја појединца, стил појединца, дискурс у ком се употребљава и сл). Када је реч о разликама у самим метафорама, оне могу бити присутне како у изворном, тако и у циљном домену, али и у разради метафоре. Различите културе „бирају” различите аспекте појава које се у метафори доводе у везу, и на другачије начине их обрађују.

Због комплексности појава које се изучавају, истраживања појмовне метафоре нису без извесних „замки”. На самом почетку тешко је уопште утврдити прецизне дефиниције динамичних и слојевитих појмова као што је 
култура, и у том смислу постоји опасност, као што истиче Бернардес (2013: 2) да се одреднице „култура” и „културно-специфично” користе да „покрију” све оно што је у теоријском приступу недоследно или мање приступачно анализи. Како је назначено описаним истраживањима, култура има утицај и на формирање преконцептуалних схема, стога је важно да истраживач буде свестан могућих предрасуда дубоко заснованих на моделима културе којој сам припада. Стога је важно бити опрезан са тврдњама о универзалности појмовних метафора, а нарочито са доношењем уопштених судова о конкретним народима и културама. Посебан проблем представља интерпретација узрочно-последичних веза у међуодносу културе, језика и мишљења - да ли добијени резултати упућују на утицај културе на језик, или обратно, или је можда чак неки други фактор играо улогу. Поменућу само још и питање испитаника и корпуса, који морају бити обимнији и разноврснији.

Упркос свим овим могућим проблемима, појмовна и културолошка метафора као аналитичка средства могу имати различите примене и дати значајан допринос разумевању различитих култура и језика, човекове способности мишљења уопште, и њиховог узајамног односа. Истраживања представљена у овом раду то и доказују, предлажући свеобухватне и суптилне увиде о културним факторима који могу бити одговорни за уочене разлике на лингвистичком нивоу.

Досадашња открића дају солидну подлогу за ближе повезивање различитих дисциплина и отварају простор за описивање још комплекснијих питања која се тичу природе метафоре. Један могући правац интердисциплинарних истраживања (који би обухватао чак и медицинску антропологију) испитивао би смерове у ком тело, језик, култура и мишљење утичу једно на друго. Посебно занимљив аспект појмовне метафоре могла би бити метафоричност телесних манифестација и израза, будући да, како истиче Кимел (2003), само тело некад изражава културна значења на метафорички начин (Шипер-Хјуз (1990) осећај подрхтавања и слабости у ногама код радника у Бразилу тумачи као испољавање метафоре „не могу више да издржим”).

\section{ЛИТЕРАТУРА}

Бернардес 2013: E. Bernárdez, On the cultural character of metaphor: Some reflections on Universality and Culture-specificity in the language and cognition of time, especially in Amerindian languages. Review of Cognitive Linguistics, 11(1), 1-35. 
Богетић 2018: K. Bogetić, Discursive metaphorical frames: The violence over language frame in Serbian and British newspaper discourse. BELLS, 10, 105-130. Бородицки 2001: L. Boroditsky, Does language shape thought?: Mandarin and English speakers' conceptions of time. Cognitive Psychology, 43, 1-22. Вјежбицка 1986: A. Wierzbicka, Human emotions: Universal or culture-specific? American Anthropologist, 88(3), 584-594.

Герартс и Гронделарс 1995: D. Geeraerts \& S. Grondelaers, Looking back at anger: Cultural traditions and metaphorical patterns. In J. Taylor \& R. MacLaury (eds.), Language and the Cognitive Construal of the World, Berlin: Gruyter, 153-158,

Гутијерес Перес 2008: R. Gutiérrez Pérez, A cross-cultural analysis of heart metaphors. Revista Alicantina de Estudios Ingleses, 21, 25-56.

Драгићевић 2010: Р. Драгићевић, Вербалне асоџијаџије кроз српски језик и културу. Београд: Друштво за српски језик и књижевност Србије.

Еманишн 1995: M. Emanatian, Metaphor and the expression of emotion: The value of cross-cultural perspectives. Metaphor and Symbol, 10(3), 163-182.

Еванс 2007: V. Evans, How we conceptualize time: Language, meaning and temporal cognition. In V. Evans, B. Bergen \& J. Zinken (eds.), The Cogitive Linguistics Reader, London: Equinox Publishing Ltd., 733-765.

Изард и Бушлер 1980: C. Izard \& S. Buechler, Aspects of consciousness and personality in terms of differential emotions theory. In R. Plutchik \& $\mathrm{H}$. Kellerman (eds.), Emotion: Theory, Research, and Experience. Vol. 1: Theories of Emotion, New York: Academic Press, 165-187.

Jy 1995: N. Yu, Metaphorical expressions of anger and happiness in English and Chinese. Metaphor and Symbolic Activity, 10(2), 59-92.

Jy 2008: N. Yu, Metaphor from body and culture. In R. W. Gibbs, Jr. (ed.), The Cambridge Handbook of Metaphor and Thought, Cambridge: Cambridge University Press, 247-261.

Касанто 2009: D. Casasanto, Embodiment of abstract concepts: Good and bad in right-and left-handers. Journal of Experimental Psychology: General, 138(3), 351-367.

Кевечеш 2003: Z. Kövecses, Language, figurative thought, and cross-cultural comparison. Metaphor and Symbol, 18(4), 311-320.

Кевечеш 2006: Z. Kövecses, Universality and variation in the use of metaphor. In N. L. Johannesson \& D. C. Minugh (eds.), Selected Papers from the 2006 and 2007 Stockholm Metaphor Festivals, Stockholm: Department of English, Stockholm University, 51-74. 
Кевечеш 2008: Z. Kövecses, Metaphor and Emotion. In R. W. Gibbs, Jr. (ed.), The Cambridge Handbook of Metaphor and Thought, Cambridge: Cambridge University Press, 380-397.

Кевечеш 2010a: Z. Kövecses, Metaphor and culture. Acta Universitatis Sapientiae, Philologica, 2(2), 197-220.

Кевечеш 2010b: Z. Kövecses, Metaphor: A Practical Introduction. New York: Oxford University Press.

Кимел 2004: M. Kimmel, Metaphor variation in cultural context: Perspectives from Anthropology. European Journal of English Studies, 8(3), 275-293.

Лангакер 1994: R. W. Langacker, Culture, cognition, and grammar. In M. Pütz (ed.), Language Contact and Language Conflict, Amsterdam/Philadelphia: John Benjamins, 25-53.

Лејкоф 2008: G. Lakoff, The neural theory of metaphor. In R. W. Gibbs, Jr. (ed.), The Cambridge Handbook of Metaphor and Thought, Cambridge: Cambridge University Press, 17-39.

Лејкоф и Џонсон 1980: G. Lakoff \& M. Johnson, Metaphors We Live By. Chicago: University of Chicago Press.

Литлмор 2003: J. Littlemore, The effect of cultural background on metaphor interpretation. Metaphor and Symbol, 18(4), 273-288.

Мацуки 1995: K. Matsuki, Metaphors of anger in Japanese. In J. Taylor \& R. MacLaury (eds.), Language and the Cognitive Construal of the World, Berlin: Gruyter, 137-151.

Палмер 1996: G. Palmer. Toward a Theory of Cultural Linguistic. Austin: University of Texas Press.

Палмер 2006: G. Palmer, Energy through fusion at last: Synergies in cognitive anthropology and cognitive linguistics. In G. Kristiansen, M. Achard, R. Dirven \& F. J. Ruiz de Mendoza Ibáñez (eds.), Cognitive Linguistics: Current Applications and Future Perspectives, Berlin: Walter de Grutyer, 263-304.

Сајахан 2008: P. Siahaan, Did he break your heart or your liver? A contrastive study on metaphorical concepts from the source domain organ in English and in Indonesian. In F. Sharifian \& R. Dirven (eds.), Culture, Body, and Language: Conceptualizations of Internal Body Organs across Cultures and Languages (Applications of Cognitive Linguistics), Berlin/New York: Mouton De Gruyter, 45-74.

Синха и Де Лопес 2000: C. Sinha \& K. J. De López, Language, culture, and the embodiment of spatial cognition. Cognitive Linguistics, 11(1/2), 17-42. 
Синха и др. 2011: C. Sinha, V. D. S. Sinha, J. Zinken \& W. Sampaio, When time is not space: The social and linguistic construction of time intervals and temporal event relations in an Amazonian culture. Language and Cognition, 3(1), 137-169.

Фоконије и Тарнер 2008: G. Fauconnier \& M. Turner, Rethinking metaphor. In R. Gibbs (ed.), The Cambridge Handbook of Metaphor and Thought, Cambridge: Cambridge University Press, 53-66.

Хијет 1978: L. R. Hiatt, Classification of the Emotions. In L. R. Hiatt (ed.), Australian Aboriginal Concepts, Canberra: Australian Institute of Aboriginal Studies, 182-187.

Цинкен, Хелстен и Нерлих 2003: J. Zinken, J. Hellsten \& B. Nerlich, What is "cultural" about conceptual metaphors? International Journal of Communication, 13(4), 5-29.

Шарифијан 2014: F. Sharifian, Conceptual metaphor in intercultural communication between speakers of Aboriginal English and Australian English. In A. Mussolff \& F. MacArthur (eds.), Metaphor and Intercultural Communication, London: Bloomsbury Publishing, 117-129.

Шарифијан 2017: F. Sharifian, Cultural linguistics. Ethnolinguistics (Etnolingwistyka), 28, 33-61.

Шипер-Хјуз 1990: N. Scheper-Hughes, The rebel body. The subversive meanings of illness. TAS Journal, 10, 3-10.

Шифелин 2002: B. Schieffelin, Marking time: The dichotomizing discourse of multiple temporalities. Current Anthropology, 43, S5-S17. 


\title{
Anđela Pendić
}

\section{CULTURE-BASED DIFFERENCES IN CONCEPTUAL METAPHORS ACROSS LANGUAGES}

\begin{abstract}
Summary
The ever-evolving study of conceptual metaphors shed a new light on this phenomenon and the importance of culture in creating meaning. It entrenched the emergence of new disciplines, including cultural linguistics. The goal of this paper is to present a brief overview of some work about cultural conceptualizations in different languages. We will try to show how culture impacts the creation of meaning and what may be the advantages of the cultural linguistic account, but also what may be misleading in this kind of research. Vast material is reduced to examples which include conceptualizations of body, time, feelings, and image schemas. Aside from these, there is also a part dedicated to cultural differences that occur depending on the context of communication. Our concise analysis leads to the conclusion that, just as seeing conceptual metaphor exclusively as a physiological phenomenon, considering only cultural factors may be equally biased. Taking into account the interplay between multiple factors can give more precise overall picture.
\end{abstract}

Keywords: conceptual metaphor, culture, cultural linguistics, cognitive linguistics, cultural metaphor, embodiment. 


\title{
Анжела Пендич
}

\section{КУЛЬТУРОЛОГИЧЕСКИЕ РАЗНИЦЫ В КОНЦЕПТУАЛЬНЫХ МЕТАФОРАХ В РАЗНЫХ ЯЗЫКАХ}

\begin{abstract}
Авторское резюме
Концептуальная метафора в новых исследованиях все чаще рассматривается не только как лингвистический, неврологический, телесный феномен, а также как культурологический феномен. Такой подход привел к развитию новых междисциплинарных областей науки, в том числе и культурологической лингвистики. В этой дисциплине в фокусе сложные взаимоотношения культуры, языка и мышления. В статье будут обсуждены некоторые ее преимущества и недостатки на немногих примерах разных концептуализаций времени, образ-схем, тела, чувств. Особую часть представляют примеры культурологических разниц в зависимости от условий и контекста коммуникации. Анализ материала показывает, что в исследовании концептуальной метафоры надо учитывать как телесный опыт, так и культурную среду. Пренебрежение одного из аспектов метафоры и предпочтение другого обычно приводит к односторонним и недостаточным выводам.

Ключевые слова: концептуальная метафора, кульура, культурологическая лингвистика, когнитивная лингвистика, культурологическая метафора, embodiment.
\end{abstract}

